\title{
No association between the PREP gene and lithium responsive bipolar disorder
}

\author{
Firoza Mamdani ${ }^{1}$, Adolfo Sequeira ${ }^{1}$, Martin Alda ${ }^{2}$, Paul Grof ${ }^{3}$, Guy Rouleau ${ }^{4}$ \\ and Gustavo Turecki*1
}

\author{
Address: ${ }^{1}$ Douglas Hospital Research Centre, McGill University, Montreal, Quebec, Canada, ${ }^{2}$ Department of Psychiatry, McGill University, \\ Montreal, Quebec, Canada, ${ }^{3}$ Mood Disorders Clinic of Ottawa, Ottawa, Ontario, Canada and ${ }^{4}$ Université de Montréal, Montréal, Quebec, Canada \\ Email: Firoza Mamdani - firoza.mamdani@mail.mcgill.ca; Adolfo Sequeira - seiado@douglas.mcgill.ca; Martin Alda - martin.alda@mcgill.ca; \\ Paul Grof - paul_grof@yahoo.ca; Guy Rouleau - guy.rouleau@mcgill.ca; Gustavo Turecki* - gustavo.turecki@mcgill.ca \\ * Corresponding author
}

Published: 26 February 2007

BMC Psychiatry 2007, 7:9 doi:10.1186/147|-244X-7-9
Received: 3 November 2006

Accepted: 26 February 2007

This article is available from: http://www.biomedcentral.com/147I-244X/7/9

(c) 2007 Mamdani et al; licensee BioMed Central Ltd.

This is an Open Access article distributed under the terms of the Creative Commons Attribution License (http://creativecommons.org/licenses/by/2.0), which permits unrestricted use, distribution, and reproduction in any medium, provided the original work is properly cited.

\begin{abstract}
Background: Bipolar disorder (BD) is a major psychiatric condition that commonly requires prophylactic and episodic treatment. Lithium (Li) has been used for over 40 years now as an effective prophylactic agent. Response to Li treatment seems to be, at least in part, genetically determined. Although we ignore how Li specifically prevents mood episodes, it has previously been suggested that Li exerts an effect on the phosphoinositide pathway, and more recently, it has been proposed that Li may modulate prolyl endopeptidase (PREP).

Methods: In this study we carried out an association study looking at the PREP gene, located on ch 6q22. Five intronic single nucleotide polymorphisms (SNP), three coding SNPs and one SNP in the 5' UTR were investigated for their frequency in a BD sample of 180 excellent Li responders, $69 \mathrm{Li}$ nonresponders and 126 controls. Genotyping was carried out using the SNaPshot reaction from Applied Biosystems, which is a modified fluorescent single base pair extension procedure.

Results: Following correction for multiple testing, no significant genotypic, allelic or estimated haplotypic differences were found between responders and nonresponders or between BD patients and controls.

Conclusion: PREP is an interesting candidate gene to investigate in genetic studies of $\mathrm{BD}$, but our findings do not support the hypothesis that genetic variation in this gene plays a major role in the etiology of BD or Li response.
\end{abstract}

\section{Background}

Lithium has been one of the most widely used and best characterized prophylactic treatments for bipolar disorder (BD). Even though the therapeutic effects of lithium have been well documented for many years, its mechanism of action remains unknown. Several plausible pathways have been hypothesized to be influenced by lithium; the phosphoinositide pathway being one [1]. It has been demonstrated that lithium inhibits two key enzymes involved in the regeneration of free inositol. One of these is inositol monophosphatase (IMPase), which is the enzyme responsible for the conversion of inositol monophosphate (IMP) to free inositol. The other one is inositol polyphosphatase (IPP), which is the enzyme catalyzing 
the transformation of inositol 1,4-bisphosphate to IMP $[2,3]$. The effects of the lithium induced inhibition results in the decrease of phosphatidyl inositol-4,5-bisphosphate (PIP2). This subsequently causes a decrease in the downstream signaling molecules, inositol-1,4,5-trisphosphate (IP3) and diacylglycerol (DAG) which are produced through the phospholipase $\mathrm{C}$ catalyzed breakdown of PIP2. This process initiates a dampening of cellular response to second messengers [4]. It is for this reason that genes involved in this pathway are good candidates for investigation

One such gene is prolyl endopeptidase or prolyl oligopeptidase (PREP). Prolyl endopeptidase has been shown to be highly active in the brain, especially in the frontal cortex and in the limbic system [5,6]. PREP is a cytosolic serine protease that has been shown to cleave neuropeptides made up of 30 residues or less, for instance thyrotropin-releasing hormone, arginine vasopressin, and others [7]. Investigating possible mechanisms of lithium's action in Dictyostelium, an amoebae used as a model system for molecular genetic studies, Williams and colleagues (1999) reported that lithium resistant mutants lacked the PREP gene and showed high levels of IP3. This increase is likely the result of the inability of Dictyostelium to dephosphorylate IP3 into IP2. Thus, these results provided experimental evidence for a link between the lack of PREP expression and increased IP3 levels. In addition, this data adds evidence to the implication of the inositol second-messenger system in BD and lithium's mode of action. These findings are in accordance with a previously reported association between abnormal PREP activity and bipolar disorder/major depression [8]. Recently, Williams et al. [9] added new results suggesting a common, underlying mechanism via inositol depletion for lithium, valproic acid and carbamazepine, all commonly used mood stabilizers for bipolar disorder. The authors showed that Dictyostelium resistance in mutants to these drugs was conferred by $P R E P$, further suggesting a possible role of prolyl endopeptidase as a mediator of these drugs' mood stabilizing action through the inositol system.

Interestingly, the PREP gene is located on chromosome $6 q 22$, a region that has been linked to BD in several studies [10-12] and most recently in Portuguese families [1315], thus providing added incentive to investigate genes in this chromosomal region.

The purpose of this paper was to investigate variation at the PREP gene in a sample of $\mathrm{BD}$ patients with either excellent lithium response or nonresponse.

\section{Methods Subjects}

The sample used for this study was composed of 251 patients with only a diagnosis of $\mathrm{BD}$. Of these patients, a hundred forty-five patients were females and 104 were male, with a mean age of $47.91 \pm 14.09$ years and a mean age of onset of $26.15 \pm 9.71$. Of the cases 180 were responders (LiR) and 69 were nonresponders (LiNR) to long term lithium treatment. All psychiatric assessments were carried out by experienced clinicians using the SADSL structured interviews, and the RDC and DSM-IV criteria. Excellent lithium response was established as described previously [16] and summarized in Table 1, with the number of pretreatment episodes ( \pm standard deviation) being $8.04 \pm 5.75$ and treatment length being $13.25 \pm 7.26$ years. Controls included in this study were 126 healthy, psychiatrically normal individuals (mean age $48.17 \pm$ 11.84) that were assessed using the same criteria as for patients. Prior to inclusion in the study, all individuals provided written informed consent. This study was approved by the local review boards of each institution. All subjects included in this study were Caucasian of European origin that were recruited in centers that are part of the International Group for the Study of Lithium (IGSLi), a collaborative group of specialized clinics in Canada, Austria, Czech Republic, Denmark, Germany, and Sweden. To ensure diagnostic uniformity across the clinics all patients were subsequently evaluated by the same senior clinician (PG).

\section{DNA analysis}

Genomic DNA was extracted using a standardized method (Sambrook et al, 1989) from venous blood samples. Nine single nucleotide polymorphisms (SNP), five intronic, three coding and one located in the 5' UTR, spaced out along the PREP gene were investigated using the ABI SNaPshot multiplex reaction and the ABI 3100 automated genetic analyzer (Figure 1). Polymerase chain reaction (PCR) was carried out in a total volume of $15 \mu \mathrm{l}$ which contained $30 \mathrm{ng}$ genomic DNA, $0.2 \mu \mathrm{M}$ of each primer, $0.25 \mathrm{mM}$ of each dATP, dNTP, dTTP and dGTP, 0.75 units of Amplitaq Gold DNA polymerase, $1.5 \mu \mathrm{l}$ of $10 \times$ buffer and $25 \mathrm{mM} \mathrm{MgCl} 2$. The samples were put through between 30 to 40 cycles of denaturation at $94^{\circ} \mathrm{C}$, annealing at specific primer temperatures, elongation at $72^{\circ} \mathrm{C}$ and a final extension at $72^{\circ} \mathrm{C}$. PCR product amplification was verified by running $5 \mu \mathrm{l}$ of product on a $2 \%$ agarose gel. The remaining product was then processed as per the ABI SNaPshot protocol, using primers designed for fluorescent dideoxy nucleotide termination. SNP analysis was carried out on the ABI 3100 genetic analyzer. Genotypes were determined automatically using the Genemapper software (Applied Biosystems). 
Table I: Criteria used to diagnose bipolar patients as excellent lithium responders

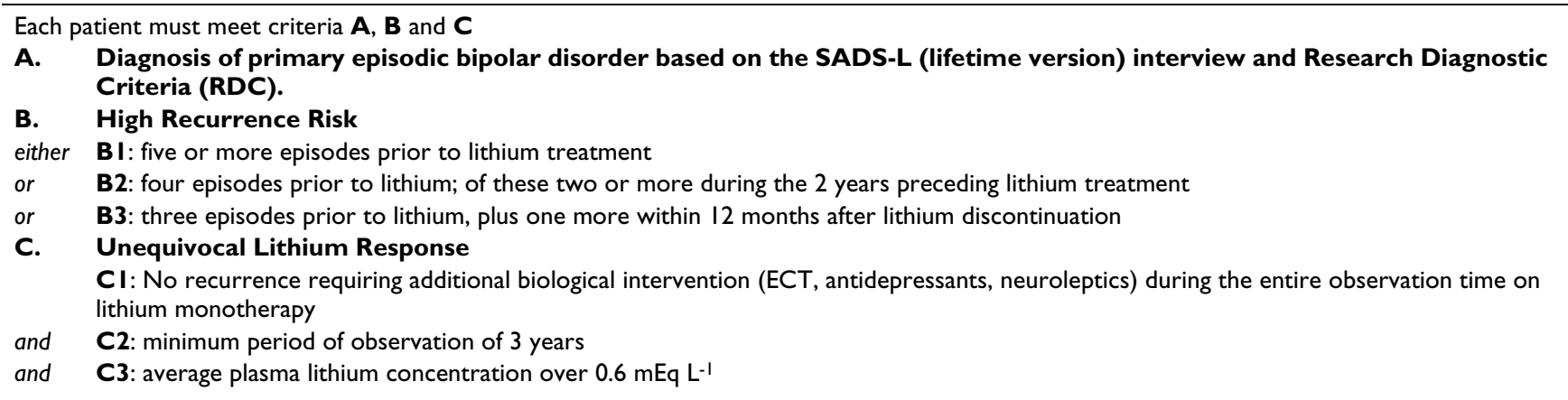

\section{Statistical analysis}

Hardy-Weinberg (HW) analysis was carried out using the Quick Chi program and those SNPs found to be in disequilibrium were not included in further analyses. Allelic and genotypic frequency distributions were compared between cases and controls, responders versus controls, nonresponders versus controls and finally responders versus nonresponders using a $\chi^{2}$ test and the computer programs SigmaStat and SPSS. Haplotype and linkage disequilibrium (LD) analyses were carried out using both GENECOUNTING and its support programs $[17,18]$. Our sample had $85 \%$ power to detect an association with a variant that is present in $35 \%$ of the general population and that doubles the likelihood of lithium response, assuming a type I error no greater than 5\%.

\section{Results}

Table 2 outlines the genotypic and allelic distribution and respective $\chi^{2}$ values for the 8 loci investigated; the PREP3 SNP was disregarded because it was in HW disequilibrium. Upon completion of analyses several positive results were found prior to correction for multiple testing, interestingly only when the lithium responder subgroup was included in the analysis. When comparing cases and controls the PREP6 GG genotype was significantly associated with $\mathrm{BD}(\mathrm{p}=0.026)$. This genotype was also found to be significantly associated with response when LiR were compared to LiNR ( $p=0.040)$ or to controls $(p=0.003)$. Furthermore, in the comparison of responders with controls, the $\mathrm{G}$ allele was significantly associated with $\mathrm{LiR}$ (p $=0.011$ ).

For PREP8 both genotypic and allelic associations were found to be significantly associated with lithium response $\left(\mathrm{GA}, \chi^{2}=7.008, \mathrm{df}=2, \mathrm{p}=0.03 ; \mathrm{A}, \mathrm{p}=0.012\right)$. PREP9 provided significant genotypic and allelic associations in the following comparisons; LiR vs. controls (TT, $\chi^{2}=6.234, \mathrm{df}$ $=2, \mathrm{p}=0.044 ; \mathrm{T}, \mathrm{p}=0.035)$ and LiR vs. LiNR (TT, $\chi^{2}=$ $7.664, \mathrm{df}=2, \mathrm{p}=0.022 ; \mathrm{T}, \mathrm{p}=0.019)$. However, after correcting for multiple testing (Bonferroni correction with 36 comparisons), these results became nonsignificant. We did not find any association between age of onset or sex with genotypic or allelic presentation (data not shown).

Estimated haplotype frequencies demonstrated no significant differences in any of the comparisons. Significant linkage disequilibrium was found for most marker pairings (PREP4/PREP7; $\mathrm{D}^{\prime}=0.539, \mathrm{p}=0.0000 ;$ PREP8/ PREP5; $\mathrm{D}^{\prime}=0.695, \mathrm{p}=0.0000 ;$ PREP8/PREP7; $\mathrm{D}^{\prime}=0.372$, $\mathrm{p}=0.00901 ;$ PREP4/PREP6; $\left.\mathrm{D}^{\prime}=0.234, \mathrm{p}=0.03160\right)$.

\section{Discussion}

The phosphoinositide pathway has garnered much interest as a potential system housing genes involved in the etiology of BD. This is mostly in part due to the inhibitory effects of lithium on key enzymes involved in the recycling and the de novo synthesis of free inositol in the cell. A novel association between this pathway and PREP, a serine protease involved in neuropeptide breakdown has been reported recently. Williams and collaborators in a series of experiments were able to provide evidence towards the existence of a common mode of action for lithium (Li), valproate (VPA) and carbamazepine (CBZ) implicating also PREP [9]. Their conclusions stem from the effects seen of each drug on the plasticity of growing neurons due to their inhibition of growth cone collapse and an augmentation of the growth cone area [9]. This group had previously characterized a lithium resistant Dictyostelium mutant, with high levels of IP3 and lacking the PREP gene [19]. With these mutants it demonstrated that the depletion of inositol is essential for the prophylactic effect of Li. This group was able to extend the inositol depletion requirement to include the function of VPA and $\mathrm{CBZ}$, further suggesting a role of PREP in the phosphoinositide pathway and in the efficacy of these drugs [9]. The substantiated support for the possible involvement of PREP in the pathophysiology of BD $[7-9,19]$ makes it a likely candidate for investigation. In this study we looked at nine SNPs located along the PREP gene for association between lithium response and BD and found no differences when comparing genotypic or allelic distribution between bipolar patients and controls or between 


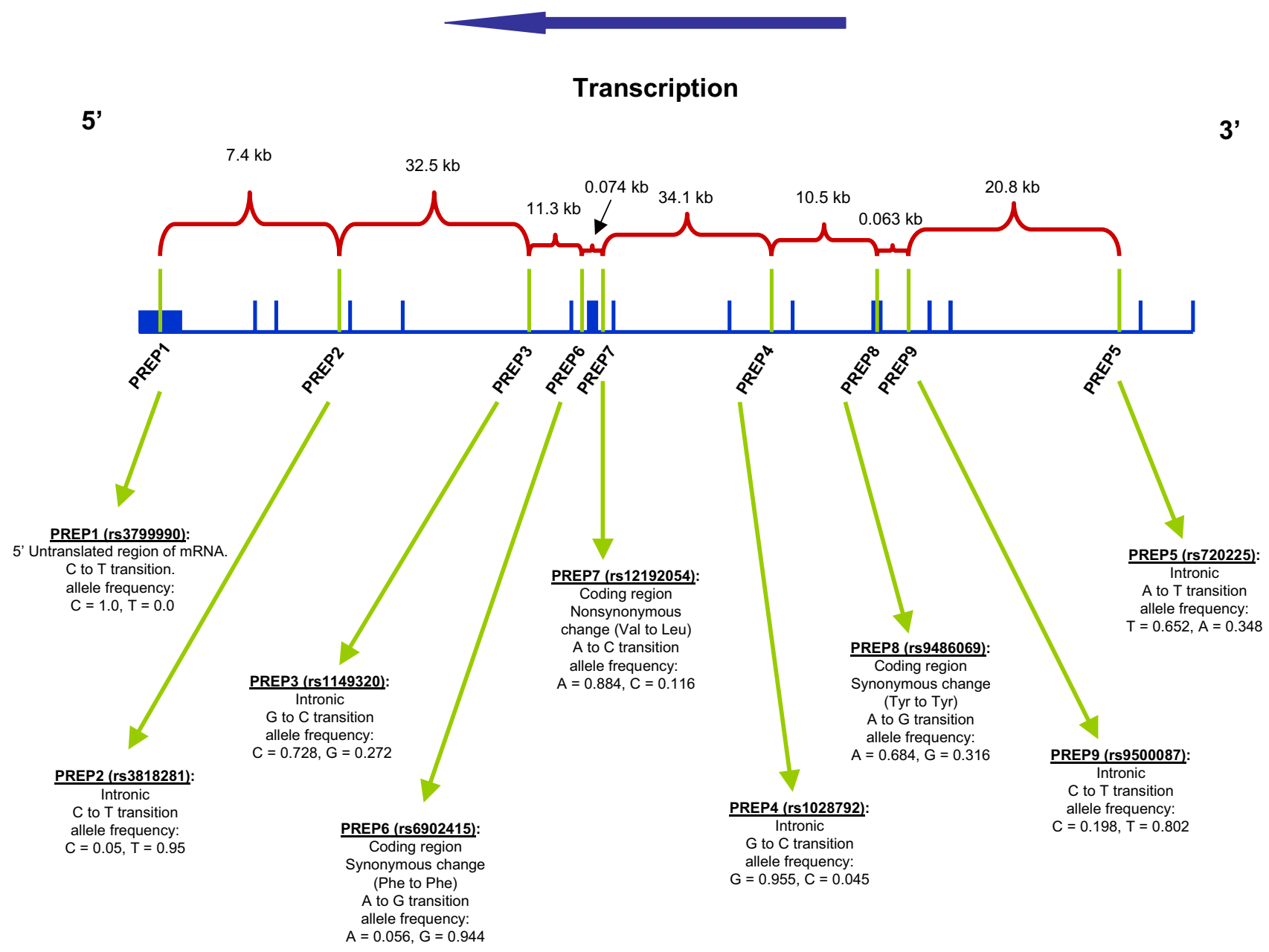

Figure I

SNP localization along the PREP gene. Location of each investigated SNP within the PREP gene with their respective allelic frequencies.

responders and nonresponders to lithium treatment following correction for multiple testing.

As it is always the case with negative association studies, it is possible that our negative results are also a consequence of methodological limitations of this study, such as reduced sample power to detect association with variants accounting for small effect sizes or limited information content of the variants investigated. In this regard, further studies using larger samples and investigating additional loci would be of interest. Moreover, expression studies could also be performed looking at the levels of the PREP protein in patients with and without good response to lithium treatment.

\section{Conclusion}

In summary our results, albeit negative, provide an initial look into the variation of a gene involved in the phospoinositide pathway and that has been shown to play a role in the mode of action of three common BD treatments; $\mathrm{Li}$, VPA and CBZ. The PREP gene is also housed in a region of linkage for $\mathrm{BD}$, which garners additional interest to determine its role in the etiology of $\mathrm{BD}$. 
Table 2: Genotypic and Allelic Frequencies for Eight SNPs Analyzed

\begin{tabular}{|c|c|c|c|c|c|c|}
\hline \multirow[t]{2}{*}{ SNP } & \multirow[t]{2}{*}{ Allele } & \multirow[t]{2}{*}{ Genotype } & \multicolumn{4}{|c|}{ Status } \\
\hline & & & Cases & Controls & LiR & LiNR \\
\hline \multirow[t]{5}{*}{ PREPI } & C & & $424(1,0)$ & $182(1,0)$ & $155(1,0)$ & $54(1,0)$ \\
\hline & $\mathrm{T}$ & & 0 & 0 & 0 & 0 \\
\hline & & $\mathrm{CC}$ & $212(1,0)$ & $91(1,0)$ & $310(1,0)$ & $108(1,0)$ \\
\hline & & $\mathrm{CT}$ & 0 & 0 & 0 & 0 \\
\hline & & TT & 0 & 0 & 0 & 0 \\
\hline \multirow[t]{5}{*}{ PREP2 } & C & & $9(0,02 \mathrm{I})$ & $21(0,111)$ & $6(0,019)$ & $3(0,027)$ \\
\hline & $\mathrm{T}$ & & $429(0,979)$ & $169(0,889)$ & $316(0,98 I)$ & $109(0,973)$ \\
\hline & & $\mathrm{CC}$ & I $(0,005)$ & 0 & 0 & I $(0,0 \mid 8)$ \\
\hline & & $\mathrm{CT}$ & $7(0,032)$ & $2 \mathrm{I}(0,22 \mathrm{I})$ & $6(0,037)$ & I $(0,0 \mid 8)$ \\
\hline & & TT & $211(0,963)$ & $74(0,779)$ & $155(0,963)$ & $54(0,964)$ \\
\hline \multirow[t]{5}{*}{ PREP4 } & G & & $391(0,968)$ & $142(0,922)$ & $283(0,969)$ & $102(0,962)$ \\
\hline & C & & $13(0,032)$ & $12(0,078)$ & $9(0,03 \mathrm{I})$ & $4(0,038)$ \\
\hline & & $\mathrm{CC}$ & $2(0,01)$ & $2(0,026)$ & I $(0,007)$ & I $(0,0 \mid 9)$ \\
\hline & & GC & $990,045)$ & $8(0,104)$ & $7(0,048)$ & $2(0,038)$ \\
\hline & & GG & $191(0,946)$ & $67(0,87)$ & $138(0,945)$ & $50(0,943)$ \\
\hline \multirow[t]{5}{*}{ PREP5 } & $A$ & & $123(0,324)$ & $73(0,397)$ & $97(0,354)$ & $26(0,26)$ \\
\hline & $\mathrm{T}$ & & $257(0,676)$ & II I $(0,603)$ & $177(0,646)$ & $74(0,74)$ \\
\hline & & $\mathrm{AA}$ & $20(0,105)$ & $21(0,228)$ & $17(0,124)$ & $3(0,060)$ \\
\hline & & AT & $82(0,432)$ & $31(0,337)$ & $62(0,453)$ & $20(0,040)$ \\
\hline & & TT & $88(0,463)$ & $40(0,435)$ & $58(0,423)$ & $27(0,54)$ \\
\hline \multirow[t]{5}{*}{ PREP6 } & $A$ & & $28(0,065)$ & $8(0,039)$ & $18(0,060)$ & $10(0,089)$ \\
\hline & G & & $404(0,935)$ & $198(0,961)$ & $284(0,940)$ & $102(0,911)$ \\
\hline & & $\mathrm{AA}$ & I $(0,005)$ & 0 & I $(0,007)$ & 0 \\
\hline & & $A G$ & $26(0,120)$ & $8(0,078)$ & $16(0,106)$ & $10(0,179)$ \\
\hline & & GG & $189(0,875)$ & $95(0,922)$ & $134(0,887)$ & $46(0,821)$ \\
\hline \multirow[t]{5}{*}{ PREP7 } & $A$ & & $345(0,88)$ & $148(0,892)$ & $22 I(0,877)$ & $108(0,885)$ \\
\hline & C & & $47(0,12)$ & $18(0,108)$ & $31(0,123)$ & $14(0,115)$ \\
\hline & & AA & $153(0,78 \mid)$ & $66(0,795)$ & $97(0,77)$ & $49(0,803)$ \\
\hline & & $A C$ & $39(0,199)$ & $16(0,193)$ & $27(0,2 \mid 4)$ & $10(0,164)$ \\
\hline & & $\mathrm{CC}$ & $4(0,020)$ & I $(0,012)$ & $2(0,0 \mid 6)$ & $2(0,033)$ \\
\hline \multirow[t]{5}{*}{ PREP8 } & $A$ & & $282(0,68 I)$ & $123(0,69 \mid)$ & $174(0,654)$ & $95(0,720)$ \\
\hline & G & & $132(0,319)$ & $55(0,309)$ & $95(0,346)$ & $37(0,28)$ \\
\hline & & AA & $98(0,473)$ & $45(0,506)$ & $58(0,436)$ & $34(0,5 \mid 5)$ \\
\hline & & $A G$ & $86(0,415)$ & $31(0,37 I)$ & $58(0,436)$ & $27(0,409)$ \\
\hline & & GG & $23(0,111)$ & II $(0,124)$ & $17(0,128)$ & $5(0,076)$ \\
\hline \multirow[t]{5}{*}{ PREP9 } & C & & $81(0,193)$ & $38(0,209)$ & $54(0,20)$ & $26(0,194)$ \\
\hline & $\mathrm{T}$ & & $339(0,807)$ & $144(0,791)$ & $216(0,80)$ & $108(0,806)$ \\
\hline & & $\mathrm{CC}$ & $7(0,033)$ & $7(0,077)$ & $5(0,037)$ & $2(0,03)$ \\
\hline & & $\mathrm{CT}$ & $67(0,319)$ & $24(0,264)$ & $44(0,326)$ & $22(0,328)$ \\
\hline & & TT & $136(0,648)$ & $60(0,659)$ & $86(0,637)$ & $43(0,642)$ \\
\hline
\end{tabular}

\section{Competing interests}

The author(s) declare that they have no competing interests.

\section{Authors' contributions}

FM performed the molecular genetic studies, carried out analysis and drafted the manuscript. FM and GT designed the experiment. AS, GT and MA helped in drafting the manuscript. MA and PG carried out psychiatric evaluations and were responsible for sample collection. GR per- 
formed the DNA extractions. All authors read and approved the manuscript.

\section{Acknowledgements}

This study was funded in part by CIHR grant I404I.

\section{References}

I. Mamdani F, Groisman IJ, Alda M, Turecki G: Pharmacogenetics and bipolar disorder. Pharmacogenomics / 2004, 4: I6I-I70.

2. Hallcher LM, Sherman WR: The effects of lithium ion and other agents on the activity of myo-inositol-I-phosphatase from bovine brain. J Biol Chem 1980, 255: I0896-1090I.

3. Sherman WR, Gish BG, Honchar MP, Munsell LY: Effects of lithium on phosphoinositide metabolism in vivo. Fed Proc 1986, 45:2639-2646.

4. Berridge MJ, Downes CP, Hanley MR: Neural and developmental actions of lithium: a unifying hypothesis. Cell I989, 59:4II-4I 9.

5. Goossens F, Vanhoof G, De M I, Augustyns K, Borloo M, Tourwe D, Haemers A, Scharpe S: Development and evaluation of peptidebased prolyl oligopeptidase inhibitors--introduction of $\mathbf{N}$ benzyloxycarbonyl-prolyl-3-fluoropyrrolidine as a lead in inhibitor design. Eur J Biochem 1997, 250:177-183.

6. Kato T, Okada M, Nagatsu T: Distribution of post-proline cleaving enzyme in human brain and the peripheral tissues. Mol Cell Biochem 1980, 32:117-121.

7. Maes M, Goossens F, Scharpe S, Meltzer HY, D'Hondt P, Cosyns P: Lower serum prolyl endopeptidase enzyme activity in major depression: further evidence that peptidases play a role in the pathophysiology of depression. Biol Psychiatry 1994, 35:545-552.

8. Maes M, Goossens F, Scharpe S, Calabrese J, Desnyder R, Meltzer HY: Alterations in plasma prolyl endopeptidase activity in depression, mania, and schizophrenia: effects of antidepressants, mood stabilizers, and antipsychotic drugs. Psychiatry Res 1995, 58:217-225.

9. Williams RS, Cheng L, Mudge AW, Harwood AJ: A common mechanism of action for three mood-stabilizing drugs. Nature 2002, 41 7:292-295.

10. Dick DM, Foroud T, Flury L, Bowman ES, Miller MJ, Rau NL, Moe PR, Samavedy N, El Mallakh R, Manji H, Glitz DA, Meyer ET, Smiley C, Hahn R, Widmark C, McKinney R, Sutton L, Ballas C, Grice D, Berrettini W, Byerley W, Coryell W, DePaulo R, MacKinnon DF, Gershon ES, Kelsoe JR, McMahon FJ, Mclnnis M, Murphy DL, Reich T, Scheftner W, Nurnberger Jl Jr.: Genomewide linkage analyses of bipolar disorder: a new sample of $\mathbf{2 5 0}$ pedigrees from the National Institute of Mental Health Genetics Initiative. Am J Hum Genet 2003, 73:107-I|4.

II. Ewald H, Flint T, Kruse TA, Mors O: A genome-wide scan shows significant linkage between bipolar disorder and chromosome I 2q24.3 and suggestive linkage to chromosomes Ip2221, 4pI6, 6qI4-22, I0q26 and I6pI3.3. Mol Psychiatry 2002, 7:734-744.

12. Mclnnis MG, Dick DM, Willour VL, Avramopoulos D, MacKinnon DF, Simpson SG, Potash JB, Edenberg HJ, Bowman ES, McMahon FJ, Smiley C, Chellis JL, Huo Y, Diggs T, Meyer ET, Miller M, Matteini AT, Rau NL, DePaulo JR, Gershon ES, Badner JA, Rice JP, Goate AM, DeteraWadleigh SD, Nurnberger JI, Reich T, Zandi PP, Foroud TM: Genome-wide scan and conditional analysis in bipolar disorder: evidence for genomic interaction in the National Institute of Mental Health genetics initiative bipolar pedigrees. Biol Psychiatry 2003, 54: I265-1273.

13. Middleton FA, Pato MT, Gentile KL, Morley CP, Zhao X, Eisener AF, Brown A, Petryshen TL, Kirby AN, Medeiros H, Carvalho C, Macedo A, Dourado A, Coelho I, Valente J, Soares MJ, Ferreira CP, Lei M, Azevedo MH, Kennedy JL, Daly MJ, Sklar P, Pato CN: Genomewide linkage analysis of bipolar disorder by use of a high-density single-nucleotide-polymorphism (SNP) genotyping assay: a comparison with microsatellite marker assays and finding of significant linkage to chromosome 6q22. Am J Hum Genet 2004, 74:886-897.

14. Pato CN, Pato MT, Kirby A, Petryshen TL, Medeiros H, Carvalho C, Macedo A, Dourado A, Coelho I, Valente J, Soares MJ, Ferreira CP, Lei M, Verner A, Hudson TJ, Morley CP, Kennedy JL, Azevedo MH, Daly MJ, Sklar P: Genome-wide scan in Portuguese Island fam- ilies implicates multiple loci in bipolar disorder: fine mapping adds support on chromosomes $\mathbf{6}$ and I I. Am J Med Genet B Neuropsychiatr Genet 2004, I 27:30-34.

15. Pato CN, Middleton FA, Gentile KL, Morley CP, Medeiros H, Macedo A, Azevedo $M H$, Pato MT: Genetic linkage of bipolar disorder to chromosome $6 \mathrm{q} 22$ is a consistent finding in Portuguese subpopulations and may generalize to broader populations. Am J Med Genet B Neuropsychiatr Genet 2005, I 34: I I9-I 2 I.

16. Grof $P, A$ lda $M$, Grof E, Zvolsky $P$, Walsh $M$ : Lithium response and genetics of affective disorders. J Affect Disord 1994, 32:85-95.

17. Zhao JH, Lissarrague S, Essioux L, Sham PC: GENECOUNTING: haplotype analysis with missing genotypes. Bioinformatics 2002 , I 8: I694-1695.

18. Zhao JH: 2LD, GENECOUNTING and HAP: Computer programs for linkage disequilibrium analysis. Bioinformatics 2004, 20: I325-1326.

19. Williams RS, Eames M, Ryves WJ, Viggars J, Harwood AJ: Loss of a prolyl oligopeptidase confers resistance to lithium by elevation of inositol $(\mathbf{1}, \mathbf{4 , 5})$ trisphosphate. EMBO J 1999, I 8:2734-2745.

\section{Pre-publication history}

The pre-publication history for this paper can be accessed here:

http://www.biomedcentral.com/1471-244X/7/9/prepub
Publish with Bio Med Central and every scientist can read your work free of charge

"BioMed Central will be the most significant development for disseminating the results of biomedical research in our lifetime. "

Sir Paul Nurse, Cancer Research UK

Your research papers will be:

- available free of charge to the entire biomedical community

- peer reviewed and published immediately upon acceptance

- cited in PubMed and archived on PubMed Central

- yours - you keep the copyright

Submit your manuscript here:

http://www.biomedcentral.com/info/publishing_adv.asp
BioMedcentral 